\title{
China's Human Rights Cooperation with the International Community
}

\section{Na Jiang*}

Associate Professor of Beijing Normal University, College for Criminal Law Science, 100875, P.R. China

\begin{abstract}
All activities which China has done in an effort to support the UN tend to promote and protect human rights and fundamental freedoms. Especially in recent developments, China's international human rights dialogues and cooperation are rather remarkable, including its membership to the Human Rights Council in 2009 and re-election for the next three-year term.
\end{abstract}

Keywords: Recent developments; China's human rights cooperation

\section{Introduction}

As a member State of the UN, China is bound by the provisions of the UN Charter and any Security Council decisions applicable to it. It has participated in a number of UN proceedings on human rights and ratified over twenty international human rights treaties, except for the International Covenant on Civil and Political Rights (ICCPR) signed in 1998 [1]. Regardless of whether China's practice does fit into these human rights standards, China gradually accepts the concept of human rights and take measures to fulfill its due international human rights obligations. It also submits reports, drafts new instruments, engages in numerous multilateral, regional or bilateral dialogues on human rights, and frequently hosts important regional or international human rights meetings in international human rights activities [2]. Following the establishment of the UN Human Rights Council, China obtained its membership by year in 2009 term election and was re-elected for a three-year term to the Council in 2009 [3]. All these activities which China has done in an effort to support the UN tend to promote and protect human rights and fundamental freedoms. Especially in recent developments, China's international human rights dialogues and cooperation are rather remarkable.

\section{General}

From the gradual disappearance of ideological labels in the 1990s, China began to take a positive attitude towards human rights matters, and increasingly attaches more importance to this cause. Since 1991 the Government of China has published White Papers on human rights to formally confirm the status of the human rights concept in the political development of China and establish China's new views and position on human rights. Moreover, 'human rights' were enshrined in the theme report of both the Fifteenth National Congress of the Chinese Communist Party (CCP) in 1997 and that of the Sixteenth in 2002 as a political concept that requires governments or the CCP to respect and protect it. This was also introduced in the 2004 Constitution as a legal concept for the first time and thus has been generally accepted as 'an important milestone' in China's human rights causes [4]. It is vital for China to carry out this principle and put it into practice because the human rights principle remains 'lifeless paper promises rather than the reality' [5] without proper implementation.

However, it is generally accepted that China has drawn a distinction between international standard-setting and implementation, which it sees as a matter of domestic jurisdiction. Also, it has been careful with those treaties to which it has become a party, not to take on any burdensome implementation of obligations. This has generated frequent condemnation from the international community, putting pressure on it to improve its compliance with the international human rights laws, which it accedes to or is a party to. As a response, from 1991, the Information Office of the State Council of the PRC issued official White Papers, on general human rights undertakings or particular issues relating to the human rights situation in China. The Chinese Government also issued the Position Paper of China at the $59^{\text {th }}$ Session of the UN General Assembly (GA) and Position Paper of the PRC on the UN Reforms, respectively in 2004 and 2005. As an addition to above White Papers, this reaffirms China's principles and position on human rights issues and supports 'the UN in reforming the human rights mechanism' [6].

At identical time, voters area unit progressively ready to challenge authorities over volatile living problems, like land seizures, forced evictions, environmental degradation, miscarriages of justice, abuse of power by corrupt cadres, discrimination, and economic difference. Official and learned statistics, supported enforcement reports, counsel there area unit 300-500 protests day by day, with anyplace from 10 to tens of thousands of participants. Despite the risks, net users and reform-oriented media area unit sharply pushing censorship boundaries by advocating for the rule of law and transparency, exposing official wrongdoing, and business for political reforms.

Civil society teams and advocates still slowly expand their work despite their precarious standing, and an off-the-cuff however resilient network of activists monitors and documents human rights cases as a loose national "weiquan" (rights defense) movement. These activists endure police observance, detention, arrest, implemented disappearance, and torture.

\section{Recent Developments}

Meanwhile, things seem to be improving slightly and gradually with the development of international human rights dialogues and cooperation. Quite apart from action within the UN, States may agree with other States about human rights standards and implementation. It is common for the EU to make human rights questions part of the

*Corresponding author: Na Jiang, Associate Professor of Beijing Normal University College for Criminal Law Science, 100875, P.R. China, Tel: + 86105880 6183; E-mail: na.jiang@bnu.edu.cn

Received July 09, 2014; Accepted December 23, 2014; Published January 03 2015

Citation: Jiang N (2015) China's Human Rights Cooperation with the International Community. Intel Prop Rights 3: 134. doi:10.4172/2375-4516.1000134

Copyright: (c) 2015 Jiang N. This is an open-access article distributed under the terms of the Creative Commons Attribution License, which permits unrestricted use, distribution, and reproduction in any medium, provided the original author and source are credited. 
dialogue they each have with States with which they trade. This enables human rights matters to be raised at a political level, without specific reference to any binding source for the human rights obligations. China has provisions similar to this in its agreements with the EU. Between 21st November and 2nd December of 2005, China consented to a visit by the UN Special Rapporteur on Torture, following another visit of an officer of the Office of the High Commissioner for Human Rights, of the $\mathrm{UN}$, in this summer. The Special Rapporteur has published his report, which was considered by the 60-year-old Commission on Human Rights (HRC) in March 2006. With its replacement with the Genevabased UN Human Rights Council as a major human rights body on March $15^{\text {th }} 2006$, China presented its candidature to the Human Rights Council and was elected as a member from 2009 to 2012.

\section{China's statements}

In applying for the membership of the Human Rights Council, the Chinese Government made an important statement on China's human rights policy and position in the aide-memoire [7]. State representatives of China shared the same opinions contained in the $1^{\text {st }}$ session of the Human Rights Council [8].

The Chinese Government is committed to the promotion and protection of human rights and fundamental freedoms of the Chinese people' [9], as 'a long-term endeavour' [10]. In recent decades, it has promoted 'social progress in all fields' and 'adopted nearly 300 laws and regulations' regarding the protection of civil and political rights [11]. Meanwhile, much work remains to be done. Following the human rights principle enshrined in the Amendment to the Constitution of the PRC in 2004, the building of 'a harmonious society featuring social justice and overall human development' became an essential part of 'the overall national development strategy'. For instance, 'building a new socialist countryside' was put forward as a goal in the $11^{\text {th }}$ FiveYear Plan for National Economic and Social Development in 2006 to effectively protect human rights.

China 'respects the universality of human rights' and cooperates with the UN to protect and promote human rights. It 'has acceded to 22 international human rights instruments'; 'earnestly fulfiled its obligations'; is creating conditions for the ratification of the ICCPR 'at an early date'; actively cooperates with the Office of the High Commissioner for Human Rights (OHCHR) [12]; the Human Rights Council and the GA [13]; responsibly responds to the communications from all the special procedures of the HRC as well as 'those transmitted through 1503 Procedure' [14].

Considering differences among countries on human rights issues, China advocated 'constructive dialogue and cooperation' [15] 'based on equality and mutual respect', and 'effective institutional safeguard' [16]. It is 'extensively engaged in such dialogues within regional, subregional and inter-regional cooperation frameworks' through hosting workshops, seminars and participating in world conferences [17]. It also holds that the Human Rights Council should 'continue to focus its attention on widespread and gross violations of human rights' [18]; equally emphasize civil and political rights and economic, social and cultural rights; 'ensure impartiality, objectivity and non-selectivity in the consideration of human rights issues'; and remove 'double standards and politicization' [19].

Furthermore, China presented another aide-memoire of the pledges and commitments to the $\mathrm{UN}$, before its re-election to the Human Rights Council. In this official document, the Chinese Government made more statements and solemn commitments on further promotion and protection of human rights in various aspects. These positive statements have contributed to China's successful campaign for membership of the Council from 2009 to 2012.

\section{The EU-China dialogue}

As one of main topics that the EU and China relations follow [20], the human rights dialogue between them was initiated in 1996 to constitute a platform for the EU to engage in China's sensitive issues 'directly to the Chinese authorities in an open and constructive atmosphere [21].' After a short break due to a critical resolution tabled by $10 \mathrm{EU}$ member States at the 1997 session of the HRC, the dialogue was resumed and 'has been held twice a year' since 1997 [22], with joint efforts of China and the EU. In support of the dialogue in a rather open and constructive atmosphere' at expert level [23], moreover, the EU-China Dialogue Seminars on Human Rights have been established since February 1998. These notably seek to promote human rights progress and the rule of law in China. The seminars in 2004 and 2005 focus on the core provisions of the ICCPR, which seeks to assist China in the ratification and implementation of the ICCPR [24]. Both sides have reached both a consensus in a series of aspects and retained disagreements on some concerns in human rights areas.

However, there are various debates and discrepancies between the EU and China. These differences are obvious and debates are heated, especially during EU-China dialogue seminars on human rights. For instance, a series of debates mainly revolve around the right to defence, judicial guarantees, fair trial, arbitrary arrest and detention, serious crimes punishable by the death penalty, and torture [25]. On the basis of these controversial issues, the EU delegation actively put forwards relevant recommendations to assist the reform of legal reforms for China's ratification of the ICCPR. Differently, the Chinese side concluded that the principles that Chinese legal systems follow are generally consistent with the ICCPR, though some legal reforms are essential. It is not a simply legal issue, but more sophisticated approaches are needed to, completely remove the discrepancies in some areas and prepare for the ratification of the ICCPR.

This appears to constitute the basic parts of the Chinese official reports on the EU-China human rights dialogue. Within such limited materials, it is difficult to find any information on the shortcomings of this dialogue or details of unrealised action points in its implementation. This seems to present China's views that this dialogue is basically successful in general and some unachieved action plans are negligible. Its positive attitude is similar to that of the EU, while the EU gave equal importance to both fruitful achievements and unsolved concerns, different from China. Accordingly, the primary problems between the EU and China are mainly manifested in the reporting of unachieved action plans, which include several aspects as follows. Firstly, China never provides 'a clear timetable' for ratification of the ICCPR or 'statistics on the use of the death penalty' as an answer to the EU [26]. There is 'no substantial progress' on 'the use of the death penalty, administrative detention and torture', to which China is willing 'to be more responsive' to them. Secondly, considerable differences between the EU and China also continue over other fundamental freedoms and rights. They mainly include 'disregard for fundamental freedoms, arbitrary detention and re-education through labour, torture, the crackdown on pro-democracy activists, the situation of minorities and capital punishment' [27]. Thirdly, in implementing the Communication of the Commission in 2003, titled with a maturing partnership-shared interests and challenges in EU-China relations, some action points fail to be properly practised in part or entirely. Specifically, the level of the human rights dialogue has not yet been 
upgraded to vice-ministerial level, the regular dialogues made marginal progress to improve remaining concerns and 'continued in the usual format' without involving more partners.

Hence, with the above actual difficulties and problems, a noticeable gap still exists 'between generally accepted international standards and the human rights situation on the ground', especially regarding civil and political rights enshrined in the ICCPR.

\section{Visits to China}

During her visit to China in 2005, Louise Arbour, an officer from the OHCHR, expressed her 'guardedly optimistic' attitude towards China's progress on human rights and 'enormous potential for positive change'. Meanwhile, numerous concerns and challenges are mentioned, mainly involving 'the extensive use of the death penalty', 'the lack of reliable data on the extent' of its use, and its improper legal procedures and the system of re-education through labour. Due to China's signing of the ICCPR and ratification of the International Covenant on Economic, Social and Cultural Rights (ICESCR), the OHCHR signed a Memorandum of Understanding (MOU) with the Government of China to help China 'remove obstacles to ratification' of the ICCPR and 'to implement recommendations' of the ICESCR during that visit. The agreement indicated the common desire of further cooperation between both sides to improve China's human rights situation.

This appears to be an important step for China to be closer to the ratification of the ICCPR by its Standing Committee of the National People's Congress. Considering the important role China plays in global human rights issues and the great concern the international community has over China's human rights situation, it is desirable to examine its potential ratification of the ICCPR in near future. This tends to clarify common misconceptions about China's human rights situation from the international society and promote understanding and cooperation between China and external bodies on such issues.

Subsequently, the UN Special Rapporteur on Torture finally realised his two-week visit to China in November 2005, '[N]early a decade after the initial request' in 1995 . He visited three places, namely, Beijing, Lhasa and Urumqi, with the aim to 'fact-finding and starting a process of cooperation' to eradicate torture in China. 'All meetings with detainees were carried out in private and in locations designated by the Rapporteur with the Ministry's help to ensure 'that the mission proceeded as smoothly as possible'. He also met 'with a number of individuals outside of his official programme', notwithstanding obstructions by 'some Government authorities'. Despite the limitations on above conditions and 'the size and complexity of China as well as the limited duration of the mission', his written report was submitted to the HRC at the 62 Session in 2006.

Specially, the Special Rapporteur both observed the relevant positive developments and highlighted challenges at the end of his visit to China. He noted that China was one of the first States to ratify the UN Convention against Torture (CAT) in 1988, but the definition of torture in Chinese legislation appears not to fully correspond to the international standard in the CAT. 'Combating torture in China is further impeded by the absence of essential procedural safeguards necessary to make its prohibition effective', 'the lack of an independent monitoring mechanism of all places of detention and a functional complaints mechanism', and 'the inefficiency of current complaint mechanisms'. He also concerns the practical circumstances surrounding the death penalty, including the situation of prisoners on death row, at the Beijing Municipality Detention Centre.
On the basis of this examination, the Special Rapporteur has put forward some preliminary recommendations to the Government of the PRC. The key ones include the following points as follows: (i) adding the crime of torture in accordance with the definition contained in CAT Article 1; (ii) reforming the criminal procedure law pursuant to ICCPR fair trial provisions; (iii) transferring several functions of the procurators to the courts; (iv) abolishing Section 306 of the Criminal Law of the PRC for lawyers' more effective representation of the rights and interest of their clients; (v) taking more measures to enhance efficiency, transparency and fairness of legal proceedings; (vi) raising the status and independence of judges and courts within the Chinese legal system; (vii) enlarging the use of non-custodial measures such as bail to reduce the number of pre-trial detainees; (viii) establishing an independent complaints mechanism for detainees subject to torture and ill-treatment; (ix) accepting the right of individuals' petition to the Committee against Torture in accordance with Articles 20 and 22; (x) abolishing any forms of forced re-education of detainees in prisons, pre-trial detention centres and psychiatric hospitals; (xi) bringing conditions on death row into line with the right of detainees with humane treatment; (xii) limiting the scope of the death penalty by abolishing it for economic and non-violent crimes; (xiii) utilizing the opportunity of the planned restoration of Supreme Court review for all death sentences to publish national statistics on the application of the death penalty; and (xiv) establishing a national human rights institution in accordance with the Paris Principles.

\section{China's re-election}

On May $12^{\text {th }} 2009$, China was re-elected for another three-year term to the UN Human Rights Council at the 63rd session of the GA This mainly results from remarkable achievements that China has made in the field of human rights since its election as a founding member of the Council in 2006. On April $13^{\text {th }} 2009$, the National Human Rights Action Plan of China (2009-2010) was published as its first working plan on human rights, pledging to further protect and improve human rights conditions in an all-round approach. It is desirable that the 'firstever human rights action plan also promises to treat detainees better and ban extraction of confessions by torture', which prohibits all forms of corporal punishment or abuse of detainees. This action plan made China becomes 'one of 26 countries that have responded to the UN's call to establish a national human rights plan since 1993'.

More importantly, China has properly fulfilled its pledges and commitments that have been made during its first application for membership of the Council. As promised, China has contributed a lot to the institution-building of the Council to promote human rights protection in many points and 'undertaken its first Universal Periodic Review (UPR) with an open and frank attitude and in a highly responsible manner.' The UPR system is a unique process and key element of the new Council which reminds States of their responsibility to fully respect and implement all human rights. Created through the GA resolution 60/251, the mechanism is designated to assess human rights situations in all member states of the UN and address human rights violations wherever they occur, once every four years. After reviewing China's human rights record in recent years, the UPR acknowledged China's efforts in human rights protection, especially its progress in promoting the right to development and poverty reduction. Thus, the Council finally adopted the outcomes of the UPR process on China in this afternoon on $11^{\text {th }}$ June 2009.

\section{Summary}

Recent developments of human rights mentioned above show that 
Citation: Jiang N (2015) China's Human Rights Cooperation with the International Community. Intel Prop Rights 3: 134. doi:10.4172/23754516.1000134

China has begun to embrace the international human rights project. It is an important step for China to cooperate with the UN on human rights matters. If China does cooperate further, then ratification of the ICCPR would be the next significant move. In the face of such an attitude, the role of proper implementation becomes more imperative than ever.

In accordance with the official media in China, China's international human rights dialogues appear to develop from just presentations of political desires to substantial and constructive dialogues on certain human rights problems. But it is worthy to be noted that China tends to report the above events more from a positive perspective that from the opposite, different from the international community. For example, the UN wholly expatiated upon Louise's visit, mentioning China's remaining concerns, its important role in global human rights causes, and the signing of the MOU. By comparison, the above Chinese news is characterized by its focus on successful progress and its omission of existing problems. More important, this is not the correspondents' abuses of literal skills, but the common official language. This appears to indicate China's in conformity with international standards. There remain problems on whether China really has insufficient knowledge on how to substantively do it or fully understands the scope and significance of its human rights obligations. This could constitute primary contents of China's constructive dialogues and human rights cooperation with the international community.

\section{References}

1. Ratification of International Human Rights Treaties-China', from University of Minnesota Human Rights Library,.

2. Information Office of the PRC, 'China's Progress in Human Rights: 2003' (March 2004, Beijing), in China's Human Rights,

3. China Re-elected to UN Human Rights Council.

4. Information Office of the PRC, 'China's Progress in Human Rights in 2004 (April 2005, Beijing), in China's Human Rights,

5. Randall P. Peerenboom, 'Human Rights and Rule of Law: What's the Relationship' (01/10/2005), from UCLA School of Law, UCLA Public Law Series, Paper 5-21
6. Information Office of the PRC, 'Building of Political Democracy in China' (October 2005, Beijing), in China's Human Rights.

7. Further 'X. Judicial Democracy'.

8. Aide Memoire'

9. Human Rights Council Begins General Substantive Debate.

10. Human Rights Council Concludes Second Day of High-Level Segment.

11. High Commissioner for Human Rights Presents Report to Human Rights Council.

12. Yang Jiechi, 'Work in Cooperation for A New Chapter in the Cause of Interantional Human Rights.

13. The EU's China Policy.

14. Political Dialogue and Human Rights Dialogue.

15. EU-China Human Rights Dialogue Seminars.

16. Ratification and Implementation of the ICCPR, and Right to Health.

17. Right to Defence, and Corporate Social Responsibility.

18. Communication of the Commission, 'A Maturing Partnership - Shared Interests and Challenges in EU-China Relations', COM (2003) 533 final.

19. Materials: Joint News Public Release on the 6th Meeting of China-EU leaders' Ziliao: Diliuci Zhong'ou Lingdaoren Huiwu Lianhe Xinwen Gongbao.

20. China Action Points/Guidelines for Action - Stocktaking April 2005', FS D (2005).

21. EU Strategy towards China: Implementation of the 1998 Communication and Future Steps for a More Effective EU Policy', COM (2001) 265 final.

22. A Maturing Partnership-Shared Interests and Challenges in EU-China Relations', COM (2003) 533 final.

23. High Commissioner for Human Rights Highlights Progress and Challenges at End of Visit to China', in UN Press Release.

24. China', in UN Press Release.

25. Special Rapporteur on Torture Highlights Challenges at End of Visit to China.

26. China Published National Human Rights Action Plan.

27. Human Rights Action Plan to Protect Detainees. 